\title{
INSTRUMENTAL MEASUREMENT OF HEALTH STATUS OF OLD NATURAL SESSILE OAK STANDS
}

\author{
Petra Trenyik ${ }^{1 *}$, Orsolya Szirmai ${ }^{2}$, Veronika MAgYar ${ }^{1}$, \\ András DeMETER ${ }^{1}$, Julianna SKUTAI ${ }^{1}$ and Szilárd CzóbeL ${ }^{1}$ \\ ${ }^{1}$ Institute of Nature Conservation and Landscape Management, Szent István University, \\ H-2100 Gödöllö, Páter K. u. 1, Hungary; *trenyikpetra@gmail.com \\ ${ }^{2}$ Botanical Garden of Szent István University, 1 Páter K., H-2100, Gödöllö, Hungary
}

Trenyik, P., Szirmai, O., Magyar, V., Demeter, A. \& Czóbel, Sz. (2017): Instrumental measurement of health status of old natural sessile oak stands. - Studia bot. hung. 48(1): 125-132.

\begin{abstract}
In Hungary increasing emphasis is put on the research regarding the naturalness of forests, because the so-called biosphere crisis - the global level degradation of our biotic environment - seriously affects the forest communities. This process can most spectacularly manifest itself in the decrease of forest size. The health status of forest stands is usually measured by visual measurements, but it is hard to eliminate subjective errors. Because of these, we carried out instrumental measurement with a 3D Acoustic Tomograph in the Köszeg Mountains, the Börzsöny Mountains and in the Zemplén Mountains. The monitoring of health status was made in sessile oak stands which were older than 100 years in 2015. We found the best health status in the stands of the Köszeg Mts. The maximum level of decay was found in the higher layers in relation to ground level because of the frost damage destroying the stands of the Börzsöny Mts. On the other hand, we experienced the highest decay in the lower levels of trunks regarding stands of the Zemplén Mts; this level of deterioration was continuously reduced towards the higher levels. The two different trends are attributable to the site conditions and the origin of the stands.
\end{abstract}

Key words: Fakopp, forest, health status, instrumental measurement, sessile oak

\section{INTRODUCTION}

The fact of climate change was confirmed by several studies, so it became accepted among scholars. It is also well known that climate change affects not only ecological systems but also the economy and social sector, because these sectors lean on the basically limited natural goods (MEA 2005). Thus it is not surprising that the study of ecosystem responses to climate change and their elements has become the most rapidly developing branch of ecology.

One of the biggest difficulties in climate research is that the responses of the living world are variable per region, per species, therefore this needs a lot of research to predict changes over space and time more precisely (e.g. WALTHER et al. 2002, Root et al. 2003, Parmesan and Yohe 2003, Parmesan 2006). According to several studies it is expected that climate-defined transition zones 
will react most sensitively to the climate change (RISSER 1995). Not only the temperature increase but also the detected and predicted precipitation patterns make the ecosystems of the Carpathian Basin vulnerable due to its geographical location (CzóBEL et al. 2010). But the answers of the ecosystems are little or not known (CzóBEL et al. 2008).

The climatic and site conditions favour the spreading of sessile oak, so there are approximately 160,000 hectares of sessile oak dominated forests in Hungary. Our continental xerophilous and mesophilous oak stands are located surrounding the plains following the range of middle mountains. Areas of the Dunántúl Mts and North Hungarian Mts with shallow topsoil and extremely dry conditions do not favour a closed canopy, because water is the minimum factor regarding these associations (MÁTYÁs et al. 1997). Many publications describe the widely known fact that because of the extreme weather the Carpathian Basin has been affected by more serious drought periods since 1970 (e.g. PIEczKA et al. 2011). Parallel with this aridification the destruction of our main forestforming species has also been observed. Among them the damage of the sessile oak proved to be severe.

The reason of the destruction was examined by several researchers e.g. IGMÁNDY et al. (1985), JAKUCs et al. (1988), and BERKI (1991, 1995). Finally VAJNA $(1989,1990)$ provided the answer to this highly complex question. In his opinion the main reason of oak decay is the aridity experienced in several years. During these periods parasitic fungi and canopy consumer insects appear in large numbers on the trees weakened by the water shortage. The degradation of the canopy affects directly on lower layers, from which often the protected, low-tolerance species disappear first. The naturalness of the stands decreases, so the colonization of the invasive species is enhanced using the emptied niche. Therefore the continuous monitoring of the stands is important, and the more accurate determination of the health status change in the light of external factors.

In case of sessile oak precipitation fulfils the most important role among climatic conditions since young individuals of this species are particularly sensitive to the lack of precipitation (MÉszÁros et al. 2012). Former researches have predicted reduced rainfall and its higher fluctuation in the Carpathian Basin in connection with climate change. It threats not only the regeneration of forest stands but also their health status (Czúcz et al. 2013).

Only a few examples of international literature involved Fakopp examinations and these studies were focused on the accuracy of the instrument. LIANG (2008) examined both the deterioration rate indicated by the instrument and the actual heartwood formation revealed after cutting the trees. The results indicated that the instrument usually overestimates the scale of deterioration in cases where cracks can be found inside the tree trunks. WANG et al. (2008) received 
the same results while examining trunks of Prunus serotina. Similar examinations were conducted by WANG et al. (2007) on 200-year-old Quercus rubra specimens; in this case health status of the trees was surveyed by not only using Fakopp instruments but also implementing visual checks. Following the felling of trees it was confirmed that both methods were suitable for identifying health issues but the instrument was able to determine the scale and place of deterioration as well.

The health status of forests is usually measured with visual methods. During the investigations the condition of the stands is determined from external signals, i.e. drying branches, leaves, and the condition of the bole. Although these measurements are very useful, but all parameters are based on estimations which are not only subjective but can also lead to inaccuracies in further calculations.

By learning these arguments we decided to implement instrumental measurements in order to determine the health status of forests.

The goal of the examination was to complete the health status check regarding 3 stocks of sessile oak found in different locations and all consisting of trees older than 100 years. The results were assessed in relation to the relevant data of annual precipitation.

\section{MATERIAL AND METHODS}

In pursuance of our examination we made measurements in three mountains (Köszeg Mts, Börzsöny Mts, and Zemplén Mts), which are situated along a west-east oriented transect that is approximately $400 \mathrm{~km}$ long. The survey was made in 100-year-old sessile oak stands in 2015.

We made contact with the competent forestry authorities, namely Szombathelyi Erdészeti Zrt., Ipoly Erdő Zrt., and Északerdő Zrt. With their help we were able to choose the most appropriate stands. The forestry officers made their management plan available for us, so we could extract the most important information from the forest stands descriptions.

To obtain comparable data we used standard parameters to sign our stands: the dominance of the sessile oak (more than $70 \%$ in the canopy), almost the same altitude $( \pm 400 \mathrm{~m})$ and gradient $\left(<15^{\circ}\right)$, as well as the fact that all sample areas lie on a south-facing hillside. The following forest stands were examined:

- Köszeg Mts Bozsok 15/C

- Börzsöny Mts Diósjenő 43/C

- Zemplén Mts Háromhuta 101/D

We worked in two quadrates in each of the three mountains. The southwest cornerstones of the quadrates were chosen randomly, the side length was 20 by 20 metres and 5 sessile oaks were signed as sample trees in every quadrate. Four of them were the nearest to the cornerstone and the fifth one was the nearest to 
the centre. We examined the health status of the trunk of all selected trees in 5 different heights $(40 \mathrm{~cm}, 80 \mathrm{~cm}, 120 \mathrm{~cm}, 160 \mathrm{~cm}$, and $200 \mathrm{~cm}$ )

We used in our investigation the Fakopp 3D acoustic tomography, which measures the speed of spread of acoustics in the tree. Each species has an optimal value, the difference - in our case: the decrease - which refers to the decay inside the tree (TRENYik et al. 2016).

During the evaluation we used the average annual precipitation values provided by the National Meteorological Service in the nearest meteorological stations: Szombathely, Diósjenő, and Tolcsva between 1961 and 2015.

For normally distributed data the t-test was applied to identify significant differences between datasets. Statistical analyses were calculated using SigmaPlot2000 (SPSS Inc., Chicago, USA). Regressions and correlations were fitted and computed using SigmaPlot2000.

\section{RESULTS}

According to the field measurements the difference between the health status of the areas is clearly visible. The trees measured in the Köszeg Mts were in the best health status; the average decay is lower than $2 \%$ in every layer. Among the layers we did not observe a clear trend which may be a result of the low rate of decay.

On the contrary, the rate of decay in oak showed a well-defined pattern layer by layer in the Börzsöny and Zemplén Mts. While the rate of decay increases towards the higher located layers in the Börzsöny Mts, the opposite can be observed in the Zemplén Mts: towards the higher layers a downward trend in the decay is measured (Fig. 1).

We display the specific decay of the stands with 3D pictures representing the most typically decayed trees (Fig. 2). We illustrated average decay and the standard deviation of 10 sample trees from each of the examined mountains on Figure 3. It clearly shows that the value of decay remained low not only in the case of each layer but also for the evaluation of each sample tree. Besides that all the standard deviation values were low which verifies the excellent health status of the whole stands. We experienced bigger fluctuation among the sample trees of the Börzsöny Mts, because frost crack only appeared on some trees. It is due to their location on the bole. This is the explanation of the low standard deviation. In the Zemplén Mts there were the highest differences among the sample trees. In this case the decay value was high as well as the standard deviation, because of the decay pattern typical of coppice forests.

Significant correlation has not been observed between the decay of the layers in the three mountains. As regards the average decay of the sample trees in each mountain the connection is significant $(P<0.05)$ between the Köszeg and Börzsöny Mts. 


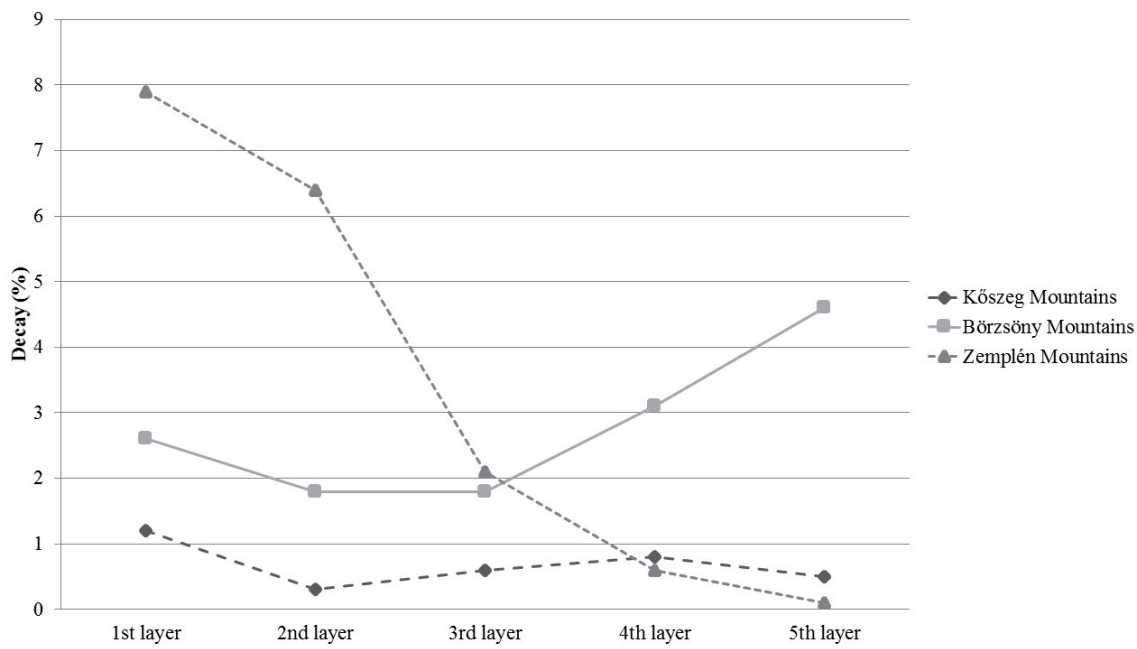

Fig. 1. Average decay value of the examined areas per layer.

Not only the origin of the stands but also the annual precipitation averages were found to be decisive factors regarding the health status of age groups (Fig. 4). The selected mountains have different climatic conditions; this is clearly reflected in the decrease of precipitation averages from West toward East.

The combined investigation of the annual average rainfall and of the decay conditions shows clearly that areas with higher precipitation indicate lower decay than drier ones (Fig. 4.).
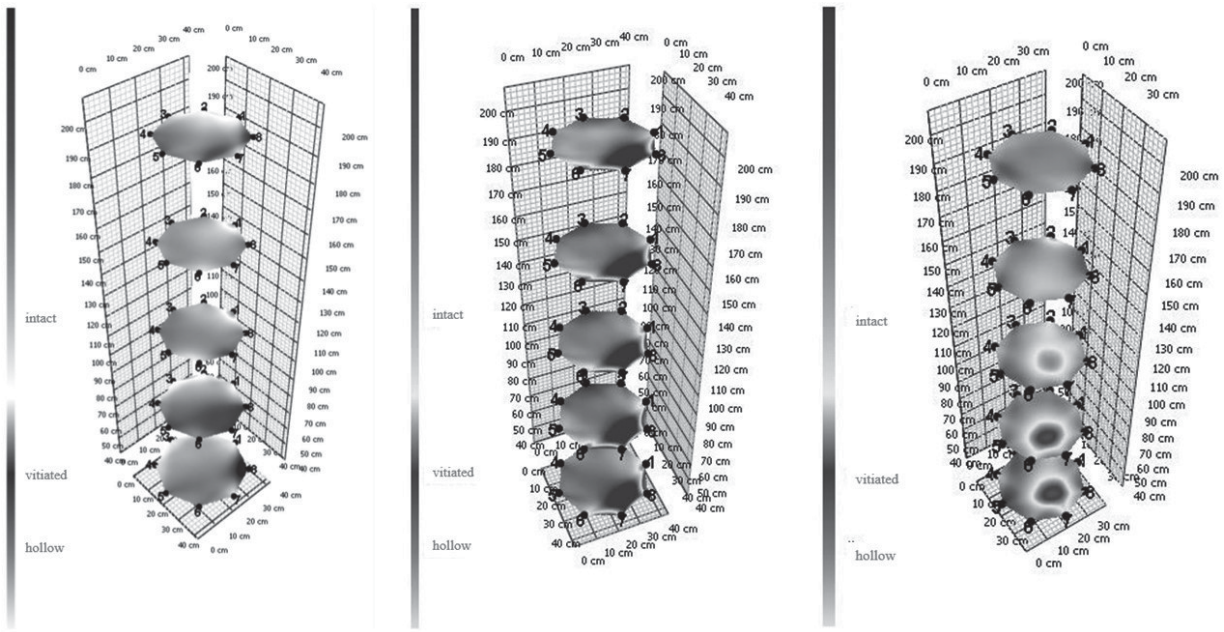

Fig. 2. 3D tomography of the sample trees of Kőszeg Mts, Börzsöny Mts and Zemplén Mts (2015). 


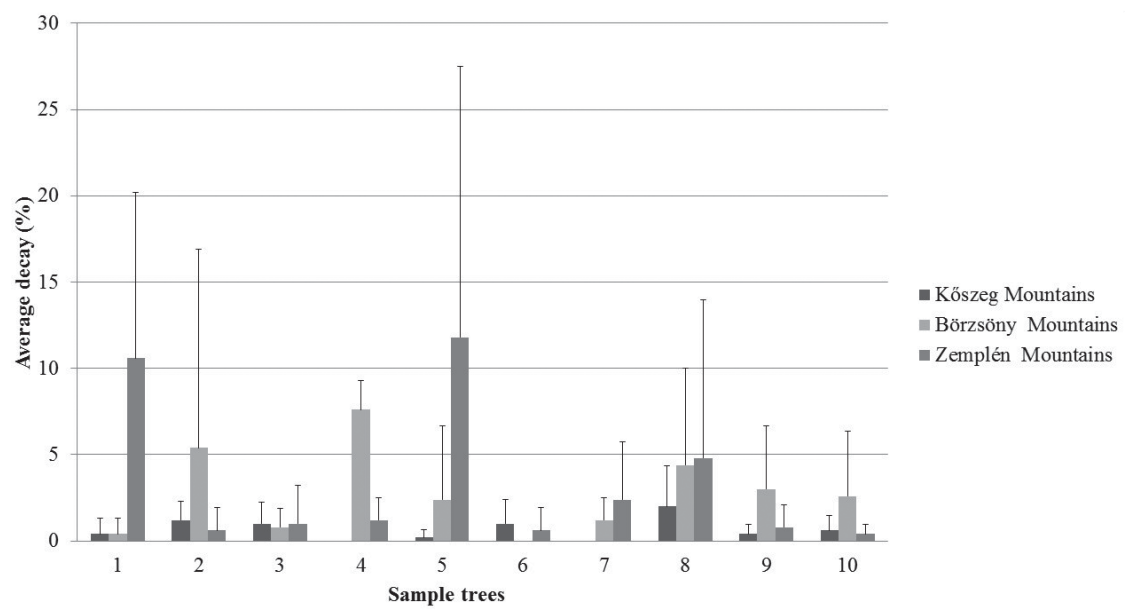

Fig. 3. Average decay and deviation per sample trees of the examined areas.

\section{DISCUSSION}

The Fakopp instrument was able to determine both the scale and place of deterioration in the selected stands, similarly to the examination implemented by WANG et al. (2007 and 2008) on old Quercus rubra trees.

It seems based on the analysis of the visual examination as well as the $2 \mathrm{D}$ and 3D figures of Fakopp measurements (Figs 1 and 2) that in the decay of the layers the origin of the stands has an important role. In the Börzsöny Mts where the stands are of seed origin the root cause of decay was the frost crack. The frost cracks were

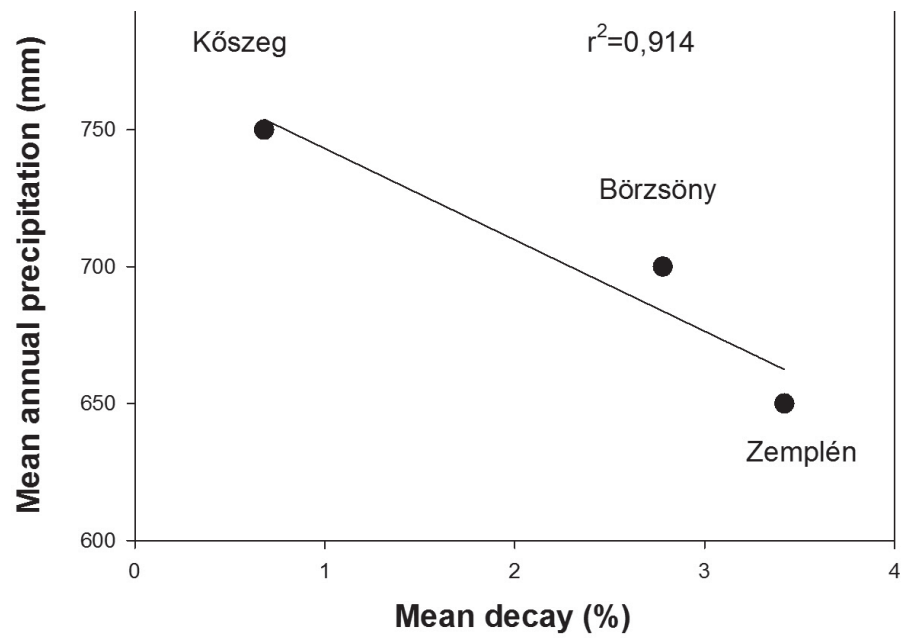

Fig. 4. Correlation between average decay and annual average rainfall. 
located farther from the ground surface mostly, therefore bigger decay values were measured in higher layers. The evaluation of the tomographies confirmed these suppositions, because the decay started from outside to inside. It is in contrast with the Zemplén age group, which is a coppice forest. Our measurements also confirmed the facts that the health status of coppice stands is poorer, they are less resistant and the extent of deterioration decreases with the distance from soil level. These trends were corroborated by the examinations carried out by TRENYIK et al. (2016) on sessile oaks older than 100 years found in the Botanical Garden of Szent István University. The cause of this was that the previous stand was cut out when it was around 100 years old, thereafter it has suckered. The lifetime of the sessile oak is around 200 years in Central Europe, so the roots of the stand are approaching the end of their lifespan.

The danger of commencing the decay is further enhanced by the open surface on the old clumps. The decay of the bole usually starts here, then spreads and spreads towards the higher levels of the bole.

Acknowledgement - This study was supported by the Research Center of Excellence - 98783/2016/FEKUT - project.

Összefoglaló: Az 1970-es évek óta több, súlyosan aszályos periódus is érintette a Kárpát-medencét. Ezzel a szárazodással párhuzamosan a fő erdőalkotó fafajaink pusztulását is megfigyelték, köztük igen súlyos mértékben jelentkezett a kocsánytalan tölgy (Quercus petraea) károsodása. Egyes prognózisok a kocsánytalan tölgy számára optimális klímatér beszükülését jelzik elö, melyek szerint a beszükülés 2050-re akár 800-100\%-os is lehet. Az erdők egészségi állapotát többnyire szemrevételezésen alapuló módszerekkel mérik fel, ám így nehezen küszöbölhetőek ki az emberi szubjektivitásból eredő hibák. Ezért a dolgozat céljául azt tủztük ki, hogy müszeres egészségi állapot felmérést fogunk végezni a Kőszegi-hegység, a Börzsöny és a Zempléni-hegység egy-egy 100 évesnél idősebb kocsánytalan tölgyes állományában. A terepi méréseink során rétegfelvételeket készítettünk az egyes mintafák törzsén, mely segítségével, százalékos pontossággal meg tudtuk állapítani a korhadás mértékét. A mérési eredményeinket az Országos Meteorológia Szolgálat mintaterületeinkhez legközelebb eső mérőállomásainak éves átlagos csapadékadataival is összevetettük. A kiértékelés során a kőszegi állományt találtuk a legjobb egészségi állapotban. A börzsönyi állományban jellemzően a talajszinthez képest magasabb rétegekben érte el a romlottság a maximumát. Ezzel szemben a zempléni állományban a törzs alsóbb rétegeiben tapasztaltuk a legnagyobb mértékủ korhadást, ami a felsőbb rétegek felé fokozatosan csökkent. A kétféle trend feltehetően a termőhelyi viszonyokra valamint az állomány eredetére vezethető vissza. Méréseink is alátámasztották azt a tényt, hogy a sarj eredetủ állományok egészségi állapota könnyebben leromlik, valamint, hogy a romlottság a gyökfötől indul, majd egyre csökken a magasabban fekvő rétegek felé.

\section{REFERENCES}

BERKI, I. (1991): Research into the cause of oak decay decline in Hungary. - Proceedings of International Symposium on Ecological Approaches of Environmental Chemicals, Debrecen, pp. 8-14.

BERKI, I. (1995): Az északi-középhegységi kocsánytalan tölgypusztulás néhány okának vizsgálata. manuscript, candidate dissertation, KLTE, Debrecen. 
Czóbel, Sz., Horváth, L., Szirmai, O., Balogh, J., Pintér, K., Németh, Z., Ürmös, Zs., Grosz, B. and Tuba, Z. (2010): Comparison of $\mathrm{N}_{2} \mathrm{O}$ and $\mathrm{CH}_{4}$ fluxes from Pannonian natural ecosystems. - Eur.J. Soil Sci. 61: 671-682. https://doi.org/10.1111/j.1365-2389.2010.01275.x

Czóbel, Sz., Szirmai, O., Nagy, J., Balogh, J., Ürmös, Zs., Péli, E. R. and Tuba, Z. (2008): Effects of irrigation on the community composition, and carbon uptake in Pannonian loess grassland monoliths. - Comm. Ecol. 9: 91-96. https://doi.org/10.1556/comec.9.2008.s.13

Czúcz, B., Gálhidy, L. and Mátyás, Cs. (2013): A bükk és a kocsánytalan tölgy elterjedésének szárazsági határa. - Erd.tud. Közlem. 3: 39-53.

Igmándy, Z., Pagony, H., Szontagh, P. and Varga F. (1985): A kocsánytalan tölgy (Quercus petraea (Matt.) Liebl.) pusztulása hazánkban. - Növényvédelem 21(7): 311-311.

JA KUCS, P. (1988): Ecological approach to forest decay in Hungary. - Ambio 17(4): 267-274.

LiAng, S., WANG, X., WiedenbaCk, J., CAI, Z. and FU, F. (2008): Evaluation of acoustic tomography for tree decay detection. - In: Ross, R. J., WANG, X. and BRAsh AW, B. K. (eds): Proceeding of the 15th international symposium on nondestructive testing of wood, 10-12 September, University of Minnesota Duluth and USDA Forest Products Laboratory Madison, USA, pp. 49-54.

MÁTYÁs, Cs. (1997): Erdészeti ökológia. - Mezőgazda Kiadó, Budapest, 312 pp.

MEA (2005): Ecosystems and human well-being: synthesis. - Island Press, Washington, 155 pp.

Mészáros, I., Fenyvesi, A. Cs., LÁposi, R., OlÁH, V. and Veres, Sz. (2012): Ecophysiological study of trees species of climate-zonal forests covering Hungarian central range, with special focus on water budget. - manuscript, project report, OTKA.

PARMESAN, C. (2006): Ecological and Evolutionary responses to recent climate change. - Ann. Rev. Ecol. Evol. Syst. 37: 637-669.

Parmesan, C. and Yohe, G. (2003): A globally coherent fingerprint of climate change impacts across natural systems. - Nature 421: 37-42. https://doi.org/10.1038/nature01286

Pieczka, I., Pongrácz, R. and Bartoly, J. (2011): Comparison of simulated trends of regional climate change in the Carpathian basin for the 21 st century using three different emission scenarios. - Acta Silvatica et Lignaria Hungarica 7: 9-22.

Risser, P. G. (1995): The status of the science examining ecotones. - BioScience 45: 318-325. https://doi.org/10.2307/1312492

Root, T. L., Price, J. T., Hall, K. R., Schneider, S. H., Rosenzweig, C. and Pounds, J. A. (2003): Fingerprints of global warming on wild animals and plants. - Nature 421: 57-60. https://doi.org/10.1038/nature01333

Trenyik, P., Szirmai, O., Barczi, A., Skutai, J. and Czóbel Sz. (2016): Examination on the state of health regarding a protected sessile oak stock. - Review of Faculty of Engineering Analecta Technica Szegedinensia 10: 23-28.

VAJNA, L. (1989): A kocsánytalan tölgy pusztulásának kórok- és járványtani kérdései. - Erdő 38: $169-175$.

VAJNA, L. (1990): Fungi associated with oak-decline. - EPPO Bulletin 20: 3.

Walther, G. R., Post, E., Convey, P., Menzel A., Parmesan, C., Beebee, T. J. C., Fromentin, J. M., Hoegh-Guldberg, O. H. and BAirlein, F. (2002): Ecological responses to recent climate change. - Nature 416: 389-395. https://doi.org/10.1038/416389a

Wang, X., Allison, R. B., Wang, L. and Ross, R. J. (2007): Acoustic tomography for decay detection in red oak trees. - FPL-RP-642, USDA Forest Service, Forest Product Laboratory. Madison, WI, USA.

WANG, X. and Allison, R. B. (2008): Decay detection in red oak trees using a combination of visual inspection, acoustic testing and resistance microdrilling. - J. Arboricult. Urb. Forest 34(1): 104 .

(submitted: 23.03.2017, accepted: 27.04.2017) 